This document was prepared in conjunction with work accomplished under Contract No. DE-AC09-96SR18500 with the U.S. Department of Energy.

This work was prepared under an agreement with and funded by the U.S. Government. Neither the U. S. Government or its employees, nor any of its contractors, subcontractors or their employees, makes any express or implied: 1 . warranty or assumes any legal liability for the accuracy, completeness, or for the use or results of such use of any information, product, or process disclosed; or 2 . representation that such use or results of such use would not infringe privately owned rights; or 3 . endorsement or recommendation of any specifically identified commercial product, process, or service. Any views and opinions of authors expressed in this work do not necessarily state or reflect those of the United States Government, or its contractors, or subcontractors. 
SED-ESV-2007-0006

Proceedings of the 15th International Symposium on the

Packaging and Transportation of Radioactive Materials

PATRAM 2007

October 21-26, 2007, Miami, Florida, USA

\title{
TECHNICAL AND REGULATORY CONSIDERATIONS IN USING FREIGHT CONTAINERS AS INDUSTRIAL PACKAGES
}

\author{
Mark Hawk \\ Oak Ridge National \\ Laboratory
}

\author{
Erich Opperman \\ Washington Savannah \\ River Company
}

\author{
Ronald B. Natali \\ R. B. Natali Consulting, Inc.
}

\begin{abstract}
The United States (US) Department of Energy (DOE), Office of Environmental Management (EM), is actively pursuing activities to reduce the radiological risk and clean up the environmental legacy of the nation's nuclear weapons programs. EM has made significant progress in recent years in the clean-up and closure of sites and is also focusing on longer-term activities necessary for the completion of the clean-up program. The packaging and transportation of contaminated demolition debris and low-level waste (LLW) materials in a safe and cost-effective manner are essential in completing this mission. Toward this end, the US Department of Transportation's (DOT) Final Rule on Hazardous Materials Regulation Final Rule issued January 26, 2004, included a new provision authorizing the use of Freight Containers (e.g., 20 and 40-foot ISO Containers) as Industrial Packages Type 1, 2, or 3 (IP-1, IP-2, and IP-3). This paper will discuss the technical and regulatory considerations in using these newly authorized and large packages for the packaging and transportation of LLW materials.
\end{abstract}

\section{INTRODUCTION}

DOE and their contractors utilize freight containers for shipments of low-level radioactive waste for disposal. Based on the classification of the material, numerous domestic shipments are required to be placed in an IP-2 or an IP-3 packaging. For materials in bulk quantities or other large materials, it is best to utilize bulk containers like freight containers, metal intermediate bulk containers, or tank containers. This paper discusses the use of freight containers as authorized by the US DOT regulations in the 49 Code of Federal Regulations (CFR) Part 173.

For many years, DOE EM, Office of Transportation, has sponsored a Packaging Management Council (here forth known as "Council”) that is open to all DOE contractors. The Council's role is to address packaging and transportation issues that are common to the DOE sites. Over the last 7 or 8 years, the Council has focused on standardizing packaging associated with waste shipments. Over the last few years, the preferred packaging of choice for waste disposal is the freight container. However, since DOE contractors are having difficulty understanding what is expected of them as offerors of these packagings to comply with the US DOT regulations, the Council has taken on the goal of determining precisely what is required for the use and documentation of freight containers to satisfy the regulations. 


\section{REGULATORY REQUIREMENTS}

Regulatory History

During the 1960's the rapid increase in the use of freight containers for the consignment of goods by sea and the development of specialized container ships caused the International Maritime Organization (IMO) to undertake a study of the safety of containerization in marine transport in 1967. The container itself emerged as the most important aspect to be considered. In 1972, a conference was held to consider a draft convention prepared by IMO in cooperation with the Economic Commission for Europe. The conference was jointly convened by the United Nations and IMO. The 1972 Convention for Safe Containers had two goals. One was to maintain a high level of safety of human life in the transport and handling of containers by providing generally acceptable test procedures and related strength requirements which would prove adequate over years of use. The other was to facilitate the international transport of containers by providing uniform international safety regulations, equally applicable to all modes of surface transport. In this way, proliferation of divergent national safety regulations could be avoided.

The requirements of the Convention apply to the great majority of freight containers used internationally, except those designed specifically for carriage by air. As it was not intended that all containers, van, or reusable packing boxes should be affected, the scope of the Convention was limited to containers of a prescribed minimum size having corner fittings - devices which permit handling, securing, or stacking. The Convention established procedures whereby containers used in international transport will be safety approved by an Administration of a Contracting State or by an organization acting on its behalf. The Administration or its authorized representative will authorize the manufacturer to affix to approved containers a safety approval plate containing the relevant technical data. The approval, evidenced by the safety approval plate granted by one Contracting State, should be recognized by other Contracting States. This principle of reciprocal acceptance of safety-approved containers is the cornerstone of the Convention; and once approved and plated, it is expected that containers will move in international transport with the minimum of safety control formalities.

The US accepted the convention requirements and adopted them January 3, 1978. The US designated the US Coast Guard as the responsible organization to ensure compliance with the International Convention for Safe Containers (CSC). This was adopted by law and incorporated into to 49 CFR Parts 450-453. To understand how the requirements of the Convention blend with the requirements for a radioactive material shipper in the US DOT regulations, a flowchart in Figure 1 reflects the steps required for using freight containers that meet the ISO 1496-1 Standard.

\section{Present US DOT Regulatory Requirements}

In 49 CFR 173.411(b)(6), the present US DOT regulations state:

Freight containers may be used as Industrial packages Types 2 or 3 (Type IP-2) or (Type IP-3) provided that:

(i) The radioactive contents are restricted to solid materials;

(ii) They satisfy the requirements for Type IP-1 specified in paragraph (b)(1); and

(iii) They are designed to conform to the standards prescribed in the International Organization for Standardization document ISO 1496-1: "Series 1 Freight Containers-Specifications and Testing--Part 1: General Cargo Containers; excluding dimensions and ratings (IBR, see Sec. 171.7 of this subchapter). They shall be designed such that if 
SED-ESV-2007-0006

subjected to the tests prescribed in that document and the accelerations occurring during routine conditions of transport they would prevent:

(A)Loss or dispersal of the radioactive contents; and

(B)Loss of shielding integrity which would result in more than a $20 \%$ increase in the

radiation level at any external surface of the freight containers.

In addition, 49 CFR 173.411(c) states:

Except for IP-1 packagings, each offeror of an industrial package must maintain on file for at least one year after the latest shipment, and shall provide to the Associate Administrator on request, complete documentation of tests and an engineering evaluation or comparative data showing that the construction methods, packaging design, and materials of construction comply with that specification.

The regulations for using freight containers as IP-2 or IP-3 packages require the offeror to take the following actions:

1. 49 CFR 173.411(b)(6)(ii): The offeror must ensure through evaluation that the freight container can meet the applicable general design requirements of 49 CFR 173.410.

2. 49 CFR 173.411(b)(6)(iii): The offeror must provide an auditable trail that the freight container being used complies with the ISO 1496-1 Standard.

3. 49 CFR 173.411(b)(6)(iii)(A): The offeror must ensure this requirement is met by performing an evaluation of the method of containment used for the contents (if any) relative to the containment characteristics of the freight container.

4. 49 CFR 173.411(b)(6)(iii)(B): The offeror must ensure this requirement is met by performing an evaluation of the shielding material required and the method of securing the shielding in place to the freight container, and /or by ensuring the payload does not shift during transport.

5. 49 CFR 174.411(b)(6)(iii): The offeror must ensure the freight container can withstand the accelerations occurring during routine conditions of transport by testing, comparison of supportive data for other similar freight containers, or container performance history using this type of container.

6. 49 CFR 173.411(c): The offeror must obtain the documentation required from the seller of the freight container, the approval agency of the freight container for the design, fabrication and testing, or the manufacturer of the freight container to comply with the documentation requirements.

\section{APPROACH TO ESTABLISHING REGULATORY COMPLIANCE}

The actions identified above have two aspects that must be satisfied. First, to satisfy the requirements in Items 2 and 6, the offeror must obtain various documents specific to the freight containers being used. Second, the offeror must perform shipment specific evaluations to comply with Items 1, 3, 4, and 5. In some instances, the container specific documentation (Items 2 and 6) may be required to perform the evaluations (Items 1, 3, 4, and 5).

The authors tried to determine what type of documentation would satisfy the requirements of Items 2 and 6 and where an offeror would obtain this documentation. For Item 2, an auditable trail needs to be developed that specifically traces the containers to the ISO 1496-1 Standard. In the authors' view, a production certificate summarizing the successful completion of all ISO 1496-1 tests and verified by the approval authority, satisfies this requirement. Since the containers are not marked to indicate compliance with the ISO standard, an offeror will need to obtain the appropriate documentation that demonstrates the container was designed and tested to 
the ISO standard. For Item 6, the offeror must obtain design drawings (or equivalent information), indicating methods of construction, materials used for construction, and details of joining (welds, bolted, etc.). To satisfy the requirement of Items 2 and 6, the offeror must obtain the documentation from the seller, approval agency, and/or the manufacturer. Since DOE sites do not procure freight containers directly from manufacturers, but from sellers, the sources for required documentation are either an approval agency or the seller.

To better understand the role of an approval agency, the documentation produced by the agency, and the availability of that documentation, the Council contacted the American Bureau of Shipping (ABS) in Houston, Texas and a meeting was arranged to discuss these items. In May 2007, ABS graciously spent the majority of a day explaining the history behind the articles of the CSC and how the articles were adopted into the domestic regulations to members of the Council. More importantly, the ABS explained the entire design, testing, and fabrication process that each designer/manufacturer must follow before a State's competent authority, or designated authorized approval agency, e.g., ABS, would certify the freight container to the CSC criteria. Included in the explanation was a discussion of the documentation submitted by the designer/manufacturer for design approval, the certificates issued by the approval agency for each phase of the process, and the availability of all these documents to an offeror/shipper.

In July 2007 Council representatives met with DOT and DOE to review regulations and discuss the information from the ABS meeting. In addition to the topics of design, testing, and fabrication of ISO-1496-1 compliant freight containers, the Council representatives made a presentation on the criteria of the CSC and the overall inspection and maintenance requirements for freight containers. As a result of this meeting, DOT requested that the DOE and Council members provide more information from major authorized approval agencies in order to determine availability of documentation. The Council members contacted four other approval agencies. The results of discussions with those agencies are presented below.

\section{Responses from Approval Agencies}

In addition to the ABS, Council members conferred with four other major approval agencies used internationally through a series of telephone conversations and e-mails. The other approval agencies that we selected included: Bureau of Veritas (BV); Det Norske Veritas (DNV); Germanischer Lloyd (GL); and Lloyd's Register (LR). Individuals contacted for each approval agency are identified under Acknowledgements in this paper. Each approval agency was requested to provide applicable sections of their rules of certification to illustrate the agency's approval process, documentation required to be submitted by the designer/manufacturer, and certificates issued by the approval agencies. Though each agency has their own titles for various certificates, most provide separate certificates of approval for the design, testing, fabrication, and the overall of production phase. When asked if the agency would provide these certificates, the responses varied; with one agency willing to provide all certificates, another agency willing to provide only the production certificate (which indicated testing performed), and the remaining three agencies requiring permission from the freight container designers/manufactures before they would provide any certificates to an offeror or owner of a freight container. All approval agencies felt a much stronger commitment to the designers/manufacturers that contracted for their services than to an offeror or owner of a freight container. All agencies agreed they would not provide the documentation submitted by designers/manufacturers (i.e., complete design drawing, calculations, etc.) for design approval as these are considered manufacturer's documents (proprietary). The approval agencies felt that offerors or owners should obtain those documents from the designers or manufacturers and felt the likelihood of obtaining those 
SED-ESV-2007-0006

documents would be very slim. Table 1 provides responses to questions asked of the five approval agencies.

\section{$\underline{\text { Responses from Sellers }}$}

Since sellers of freight containers are the only entity DOE sites have contracts with, Council members also contacted four sellers to determine what documentation, if any, could be obtained. These four sellers provide freight containers to numerous DOE sites. Each seller was asked, "if they received a purchase order that requested the following documents and information, would they be able to provide it?”

- Freight Container Test Report (including production certificates, prototype testing certificates, fabrication documents);

- fabrication drawings showing methods of construction; and

- design calculations.

Two sellers do not supply the documentation to their customers and felt if it was requested, they would not be able to obtain the proper documentation.

The other two sellers felt, in contrast to the approval agencies, that the documentation could initially be obtained from manufacturers under certain conditions. Both sellers also felt the availability of documentation is easier to obtain for new containers versus previously sold or used containers.

One seller stated that the approval agency certificates for design, testing, and fabrication of new containers are available, if requested, when the units are procured; however, requesting this information may require a longer delivery time and could impact cost. For containers that have been removed from international service and sold to DOE Contractors as used containers, they felt that it will be more difficult to get the more detailed information (e.g., Test Report), but the primary approval certificate (e.g., a Production Certificate) should be available.

The second seller felt that for new freight containers, they could go directly to the manufacturer to get the documentation for the first order or two; however, because DOE sites only procure from 1 to 10 containers at one time, the manufacturers over time would be unwilling to sell to DOE Contractors because the cost and aggravation of producing the documentation would be too high on such small orders. In addition, the second seller also felt requesting this documentation would delay the delivery of the containers and would cost additional money. This seller did indicate that if the DOE Contractors purchased in large quantities (i.e., several hundred units), they would have no problem in getting the necessary documentation and would have it available for each DOE Contractor. Also, the seller indicated that it could store the freight containers at their facility and make the containers available to DOE Contractors upon request. It should be noted that this approach might work well for freight containers that are purchased as new or in a like new condition. For freight containers that are used, meaning pulled out of international service and sold to DOE Contractors, and may not have current CSC plates; getting this same information would be essentially impossible. However, if a DOE Contractor works to get the CSC plate current, which will require inspections and possible repairs ensuring compliance to the CSC and ISO 1496-1 requirements, these documents may be available. 


\section{CONCLUSIONS}

Based on our understanding of the regulatory requirements, the discussions and information provided by the five (5) approval agencies, and the discussions with four (4) suppliers of freight containers to the DOE complex, the following conclusions are made:

1. Freight containers, designed, tested, and fabricated to the ISO 1496-1 Standard, are an alternative means of packaging and are not required to be subjected to the IP-2 or IP-3 tests.

2. The production certificates provide documentation that the container has met the ISO 1496-1 Standard and is generally available.

3. Unlike testing of IP-2 or IP-3 containers with similar contents to that which will be loaded and transported, a freight container is designed to retain its integrity under the range of ISO 1496-1 loads and pressures, and keep the weather out. Hence, when using freight containers as IP-2 or IP-3 packages, the offeror needs to load the container with contents (evaluated to contain the radioactive material under routine conditions of transport) and secure the contents so it does not shift under routine conditions of transport (so dose rates do not change).

4. The current regulations do not appear to credit the extensive efforts by the various approval agencies to meet the CSC criteria. The process for approving freight containers to the CSC criteria and/or the ISO 1496-1 Standard requirements is very similar in rigor to the process for approval of Type B containers. For both types of containers, designs are reviewed and approved, performance testing is required, and a quality assurance program for fabrication must be verified.

5. Unless large quantities of containers are procured at one time, the offeror and respective supplier may have difficulty obtaining comprehensive documentation necessary to comply with the US DOT regulations. This documentation would include:

a. Verification documents that the freight containers being procured are designed, tested, and fabricated to the ISO 1496-1 Standard to meet 49 CFR 173.411(b).

b. Complete documentation of tests and an engineering evaluation or comparative data showing that the construction methods, packaging design, and materials of construction as required by 49 CFR 173.411(c).

6. If an offeror is able to obtain documentation that is more detailed than the production certificate (e.g., test report, production test certificate), what is its value to the offeror? This documentation, especially the testing documents, does not provide the same type of information that normal IP-2 or IP-3 test documents provide. Freight containers designed and tested to the ISO 1496-1 Standard (static tests) are not allowed to have any permanent deformation, whereas, most IP-2 or IP-3 containers do experience permanent deformation during (drop) testing.

7. The current DOT radioactive material regulations do not address the continued maintenance and inspection requirements identified in the CSC criteria or the continual examination program required by the US Coast Guard in 49 CFR 452.

\section{Suggested Path Forward}

To confirm the understanding of the Council regarding the documentation requirements to use freight containers as IP-2 or IP-3 packages, the Council has prepared and submitted a Request for Clarification letter on behalf of the US DOE to be forwarded to the US DOT. The Council is presently waiting for DOT's response. 
SED-ESV-2007-0006

\section{ACKNOWLEDGMENTS}

George D. Smith

American Bureau of Shipping

Senior Engineer, Container Certification

ABS Plaza

16855 Northchase Drive

Houston, TX 77060

Brandon Caraway

Det Norske Veritas

Senior Engineer, DNV

Energy Systems Components

16340 Park Ten Place, Suite 100

Houston, TX 77084

Geoff Rogers

Lloyd's Register EMEA

Containers Consultant, UK Asset Management, Coventry

\section{REFERENCES}

International Convention for Safe Containers, 1972

Classification and Certification

Application for Certification, Chapter 1, Bureau Veritas

Rules for Classification and Construction, Ship Technology, 1995

Germanischer Lloyd

Vorsetzen 32, D-20459

Hamburg, Germany
John Palkovics

Bureau of Veritas

Houston, TX 77060
Andreas Heubner

Germanischer Lloyd

Head Department MCC - Container

Technology

Vorsetzen 35

20459 Hamburg, Germany

Rules for Certification of Casrg

Container, 1998

American Bureau of Shipping

Two World Trade Center, $106^{\text {th }}$ Floor

New York, NY 10048 USA

Rules for Certification of Freight

Container, November 1981

Det Norske Veritas

Veritasveien 1,

1322 Hovik, Norway

Lloyd's Register EMEA

Container Certification Scheme

Uk Industry Operations, Container Services

Hiramford

Middlemarch Office Village Siskin Drive

Coventry CV34FJ

United Kingdom 


\section{Table 1. Comparison of Approval Agencies of Freight Containers}

The following information was obtained during communications with the following authorized freight container approvers:

\begin{tabular}{|c|c|c|c|c|c|c|}
\hline Item & Questions & $\begin{array}{l}\text { American } \\
\text { Bureau of } \\
\text { Shipping }\end{array}$ & Bureau Veritas & $\begin{array}{l}\text { Det Norske } \\
\text { Veritas }\end{array}$ & $\begin{array}{l}\text { Germanischer } \\
\text { Lloyd }\end{array}$ & $\begin{array}{c}\text { Lloyd's } \\
\text { Register } \\
\text { of Shipping }\end{array}$ \\
\hline 1 & $\begin{array}{l}\text { What documents are produced by approval agencies } \\
\text { for certification of design, fabrication, and testing? }\end{array}$ & $\begin{array}{c}\text { Production } \\
\text { Certificate, } \\
\text { Prototype } \\
\text { Test Certificate, } \\
\text { Container Test } \\
\text { Report }\end{array}$ & $\begin{array}{c}\text { Container Factory } \\
\text { Approval } \\
\text { Certificate, Type } \\
\text { Approval } \\
\text { Certificate, } \\
\text { Examination } \\
\text { Report, Inspection } \\
\text { Certificate }\end{array}$ & $\begin{array}{l}\text { Type Approval } \\
\text { Certificate w/ } \\
\text { Summary Report, } \\
\text { Freight }\end{array}$ & $\begin{array}{l}\text { Type Certificate } \\
\text { which includes } \\
\text { tests performed on } \\
\text { the design }\end{array}$ & $\begin{array}{l}\text { Type Certificate, } \\
\text { Prototype Test } \\
\text { Report }\end{array}$ \\
\hline 2 & Are design documents submitted by manufacturer? & Yes* & Yes* & Yes* & Yes* & Yes* \\
\hline 3 & $\begin{array}{l}\text { What documents (from } 1 \& 2 \text { above) will be provided } \\
\text { to owners/shippers by the approval agency upon } \\
\text { request without contacting designer/manufacturer? }\end{array}$ & $\begin{array}{l}\text { All Item } 1 \\
\text { documents }\end{array}$ & $\begin{array}{l}\text { None, documents } \\
\text { are considered } \\
\text { confidential }\end{array}$ & $\begin{array}{l}\text { None, documents } \\
\text { are considered } \\
\text { confidential }\end{array}$ & $\begin{array}{l}\text { Type Certificate } \\
\text { which includes } \\
\text { tests performed on } \\
\text { the design }\end{array}$ & $\begin{array}{l}\text { None, } \\
\text { documents are } \\
\text { considered } \\
\text { confidential }\end{array}$ \\
\hline 4 & $\begin{array}{l}\text { What documents (from } 1 \text { \& } 2 \text { above) will be provided } \\
\text { to owners/shippers upon request after approval agency } \\
\text { receives approval from designer/manufacturer? }\end{array}$ & $\begin{array}{c}\text { Only } \\
\text { Item } 1 \text { documents }\end{array}$ & $\begin{array}{c}\text { Only } \\
\text { Item } 1 \text { documents }\end{array}$ & $\begin{array}{c}\text { Only } \\
\text { Item } 1 \text { documents }\end{array}$ & $\begin{array}{c}\text { Only } \\
\text { Item } 1 \text { documents }\end{array}$ & $\begin{array}{c}\text { Only Item } 1 \\
\text { documents }\end{array}$ \\
\hline 5 & $\begin{array}{l}\text { Do the approval agency's rules for construction } \\
\text { require that the design, fabrication, and testing be in } \\
\text { accordance with ISO 1496-1? }\end{array}$ & $\begin{array}{c}\text { Yes, unless } \\
\text { specified } \\
\text { otherwise. Tests } \\
\text { in Ch. } 7 \text { are the } \\
\text { same as the tests } \\
\text { in the ISO 1496-1 } \\
\text { Std. }\end{array}$ & $\begin{array}{l}\text { Have not seen the } \\
\text { complete Rules of } \\
\text { Construction, but } \\
\text { Examination } \\
\text { Report }\end{array}$ & Yes & $\begin{array}{l}\text { No, per Section 1, } \\
\text { Par.2.2 }\end{array}$ & $\begin{array}{l}\text { Yes, per Ch. 3, } \\
\text { Par.1.1.1-.3, } \\
\text { unless specified } \\
\text { as non-ISO }\end{array}$ \\
\hline 6 & $\begin{array}{l}\text { Which document indicates the tests that were } \\
\text { performed on a specific design? }\end{array}$ & $\begin{array}{l}\text { Prototype Test } \\
\text { Certificate }\end{array}$ & & Summary Report & Type Certificate & $\begin{array}{l}\text { Prototype Test } \\
\text { Report }\end{array}$ \\
\hline
\end{tabular}

* Approval Agency requires drawings showing arrangements, dimensions, scantlings of strength members, corner fittings, and design details as well as specification of materials to be used, details of joining methods (welding, riveting, screw connections, adhesive joints, etc), calculations as required for container type, and other documentation, as required. 


\section{ISO 1496-1 FREIGHT CONTAINER FLOW CHART}

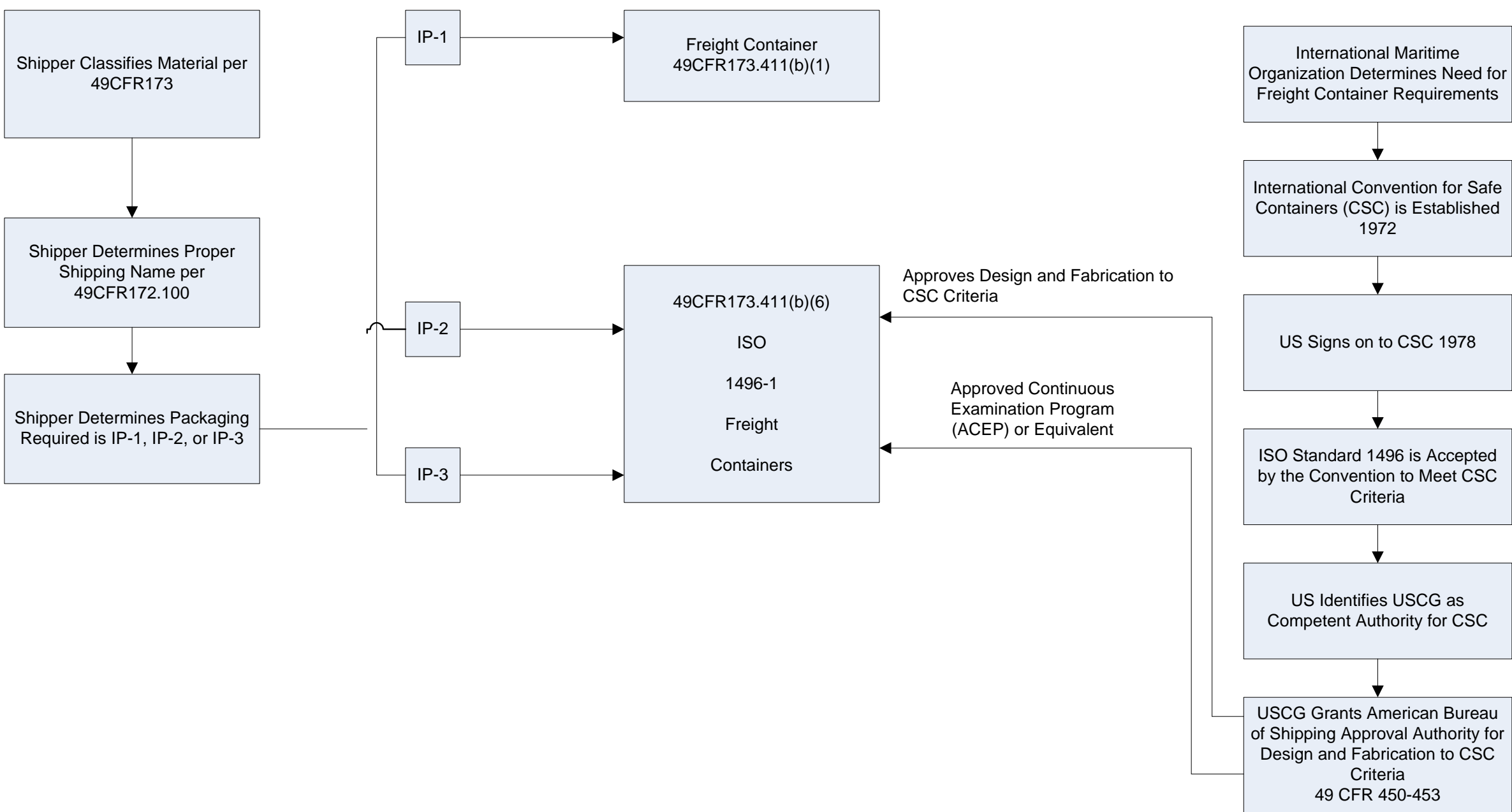

Figure 1. ISO 1496-1 Freight Container Flowchart. 